\title{
Pengaruh Pelatihan dan Disiplin Mengajar Terhadap Kualitas Pengelolaan Pembelajaran Guru PAI SMA - SMK Negeri Kota Metro.

\author{
Mia Sumiati ${ }^{1 *}$ \\ ${ }^{1}$ SMK Negeri 3 Metro \\ *E-mail: miasu77@mail.com
}

\begin{abstract}
Abstrak
Tujuan yang ingin dicapai dalam penelitian ini adalah untuk mengetahui adakah pengaruh yang signifikan pelatihan terhadap kualitas pengelolaan pembelajaran, adakah pengaruh yang signifikan dispilin mengajar terhadap kualitas pengelolaan pembelajaran, dan adakah pengaruh yang signifikan antara pelatihan dan disiplin mengajar terhadap kualitas pengelolaan pembelajaran guru PAI di SMA-SMK Negeri Kota Metro. Sehingga hasil penelitian ini dapat digunakan sebagai sumbangsih dalam rangka meningkatkan kualitas pengelolaan pembelajaran guru PAI.

Penelitian ini bersifat kuantitatif menggunakan desain penelitian survai dengan sifat penelitiannya adalah ex-postfacto. Data fakta dan informasi dijaring dengan instrumen penelitian berupa angket, pengamatan dan pengumpulan data sekunder. Populasi dalam penelitian ini adalah semua guru Pendidikan Agama Islam (PAI) di SMA- SMK Negeri Kota Metro dengan jumlah guru sebanyak 30 orang, sehingga penelitian ini termasuk penelitian populasi.

Hasil analisa data menunjukkan bahwa ada pengaruh pelatihan terhadap kualitas pengelolaan pembelajaran, ada pengaruh disiplin mengajar disebut terhadap kualitas pengelolaan pembelajaran, dan ada pengaruh secara bersama-sama antara pelatihan dan disiplin mengajar terhadap kualitas pengelolaan pembelajaran guru PAI di SMA-SMK Negeri Kota Metro. Adapun kontribusi pelatihan dan disiplin mengajar sebesar dengan $R=0,84$ koefisien persial $R 2=0,70$ atau sebesar $70 \%$ terhadap kualitas pengelolaan pembelajaran.
\end{abstract}

Kata kunci: Pelatihan, Disiplin Mengajar dan Kualitas Pengelolaan Pembelajaran.

\section{PENDAHULUAN}

Allah SWT memberikan potensi pada diri manusia berupa fitrah yang melekat pada dirinya, panca indera serta daya pikir untuk mendapatkan bermacam-macam ilmu pengetahuan melalui proses pembelajaran. Sebagaimana firman Allah SWT:

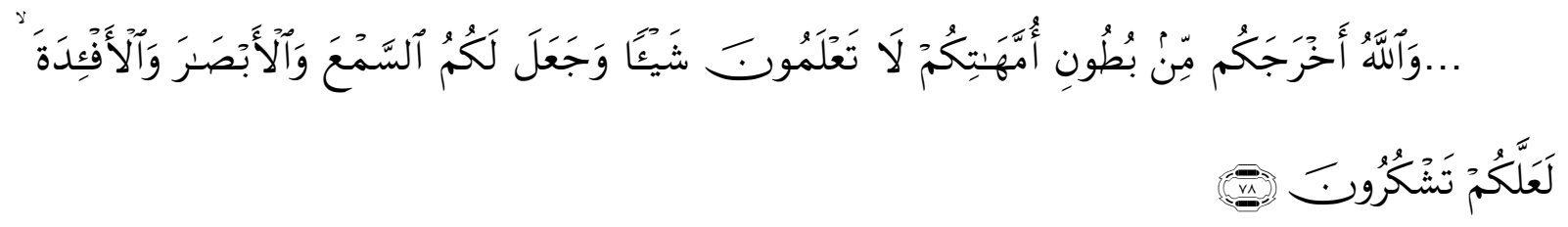

Artinya: dan Allah mengeluarkan kalian dari perut ibu-ibu kalian dalam keadaan tidak mengetahui sesuatupun, dan Dia memberi kalian pendengaran dan penglihatan dan hati agar kalian bersyukur. (Qs.Annahl: 78) ( Departemen Agama RI, AIQur'an dan terjemahan)

Menurut Pupuh Fathurrohman dan Sobry Sutikno, dalam ayat di atas menunjukkan bahwa semua sarana ini semestinya bisa digunakan dengan sebaik-baiknya ,seorang guru sebagai pendidik harus menyadari bahwa mendidik dan mengajar merupakan kewajiban yang harus dilaksanakan. (Pupuh Fathurrohman, M. Sobri Sutikno) Oleh Karena itu seorang guru harus mengutamakan kualitas pembelajaran.

Kualitas pembelajaran merupakan unsur penting di berbagai lembaga pendidikan dari tingkat dasar sampai Perguruan Tinggi. Banyak aspek yang terlibat dalam upaya meningkatkan kualitas pembelajaran, dari unsur guru, unsur siswa, sumber bahan, waktu, sarana dan prasarana. 
Dari unsur guru, pembelajaran akan berkualitas apabila guru konsisten dengan tugas dan kewajibannya, memiliki ketrampilan di bidang pembelajaran, menguasai landasan-landasan kependidikan sebagaimana aspek-aspek kompetensi dasar keguruan. ( Hamzah B. Uno,2009:34) Berdasarkan hasil penelitian oleh Marlina bahwa ada pengaruh positif dan signifikan antara disiplin dalam pempelajaran terhadap kinerja guru. Sehingga dapat digunakan sebagai sumbangsih pemikiran dan informasi serta pengetahuan dalam rangka meningkatkan keberhasilan pembelajaran.(M.Marlina,2016).

Pembelajaran yang unggul memerlukan para guru yang professional sebagai produk dari profesionalisasi secara berkelanjutan melalui pendidikan dan pelatihan secara khusus sehingga melahirkan para guru yang memiliki (1) Profesionalitas yaitu sikap mental merasa bangga dan komitmen terhadap pekerjaannya (2) Profesionalisme, yaitu sikap mental untuk komitmen terhadap kinerja bermutu sesuai dengan standar yang diharapkan baik sisi pengetahuan, sikap dan ketrampilan. ( Hanafiah dan Cucu Suhana,2010:103)

Begitu pula dengan peran guru Pendidikan Agama Islam (PAI) selain sebagai guru pada umumnya juga sebagai pondasi yang dapat melahirkan peserta didik sebagai manusia indonesia yang beriman dan bertaqwa kepada Tuhan yang Maha Esa. Pendidikan dapat menimbulkan pengaruh serta perubahan pada diri pribadi peserta didik. Suatu perubahan bukanlah terjadi hanya secara kebetulan melainkan akibat dari adanya suatu sebab musabab yang bermacam-macam untuk suatu perubahan mencapai tingkat kemajuan.

Untuk meningkatkan perubahan dalam bidang Pendidikan Agama Islam adalah perlu adanya tenaga ahli yaitu guru mata pelajaran Pendidikan Agama Islam untuk mengelola proses pembelajaran dengan kata lain mempersiapkan generasi muda yang berpengetahuan, berpengalaman dan memiliki ketrampilan serta bertaqwa kepada Allah Swt.

Kenyataan yang ada di lapangan menunjukkan bahwa pengelolaan pembelajaran guru PAI masih perlu ditingkatkan. Gejala-gejala yang dapat diamati yaitu dari segi administrasi (perangkat) pembelajaran, beberapa guru PAI masih belum melengkapi perangkat pembelajaran sampai kegiatan pembelajaran dilaksanakan. Kemudian dari segi kedisiplinan dalam melaksanakan kegiatan pembelajaran, seperti kehadiran disekolah, masuk dan keluar kelas beberapa guru PAI masih belum melaksanakan secara tepat waktu. Selanjutnya kondidsi dalam melaksanakan pembelajaran, beberapa guru PAI kondisinya dirasa masih kurang seperti perhatian siswa saat guru menyajikan materi pelajaran, ketenangan siswa di kelas, frekuensi siswa membaca dan sebagainya.

Kegiatan survai penulis lakukan pada tanggal 10 agustus 2011 dengan menginterviu kepala sekolah dan diperoleh keterangan dan data tentang guru PAI sebagai berikut:

Tabel 1.: Hasil Interviu tentang Aktivitas Guru PAl dalam Mengelola Pembelajaran.

\begin{tabular}{|l|l|l|}
\hline No. & \multicolumn{1}{|c|}{ Unsur Yang Ditanyakan } & Keterangan \\
\hline 1 & Pembuatan Perangkat Pembelajaran & Kurang \\
2 & Penguasaan materi & Cukup \\
3 & Kemampuan menerapkan metode dalam pembelajaran. & Kurang \\
4 & Penguasaan kelas & Kurang \\
5 & Ketepatan waktu memulai dan mengakhiri pembelajaran. & Kurang \\
6 & Kepemimpinan & Cukup \\
\hline
\end{tabular}

Sumber: Hasil Interviu tanggal 10 Agustus 2011

Pelaksanaan tugas mengajar atau mengelola pembelajaran yang didasari oleh pengetahuan yang cukup, sikap disiplin dan profesional, diharapkan akan memberikan kontribusi 
terhadap efektifitas pembelajaran. Banyak jenis kegiatan yang harus dilakukan guru dari penyusunan perencanaan pembelajaran sampai pada tahap evaluasi. Masing-masing tahap kegiatan harus dilaksanakan secara sistematis dengan memanfaatkan sarana dan sumber bahan yang tepat, sehingga setiap tahapan pembelajaran dapat dicapai dengan optimal. Terwujud tidaknya kualitas pengelolaan pembelajaran dapat dilihat melalui beberapa aspek pada guru PAI itu sendiri seperti: tersusunnya perankat pembelajaran secara rapi, tingkat kedisplinan yang meningkatnya. Dari aspek siswa seperti: penyerapan materi pembelajaran, peningkatan kecakapan, keterampilan serta kecakapan, kemampuan penguasaan konseptual, dan dapat pula dicerminkan dalam bentuk nilainilai hasil belajar.

Gambaran umum keberadaan dan kinerja guru PAI dalam kaitannya dengan kualitas pengelolaan pembelajaran di SMA-SMK Negeri Kota Metro dapat diuraikan sebagai berikut:

1. Seluruh guru PAI yang ada telah memiliki pendidikan formal dengan strata satu (S1). Umumnya guru PAl telah mengikuti kegiatan pelatihan, namun belum menunjukkan kemampuan dalam merancang skenario pembelajaran yang tepat.

2. Masih terdapat guru yang kurang konsisten dalam menjalankan tugas mengajar, salah satu contoh pembuatan perangkat pembelajaran dilakukan setelah pembelajaran berjalan beberapa pertemuan,

Kondisi ini menarik untuk diadakan penelitian lebih lanjut guna mengetahui keadaan yang sebenarnya.

\section{METODE/EKSPERIMEN}

Penelitian ini bersifat kuantitatif menggunakan desain penelitian survai dengan sifat penelitiannya adalah ex-postfacto. Data fakta dan informasi dijaring dengan instrumen penelitian berupa angket, pengamatan dan pengumpulan data sekunder. Populasi dalam penelitian ini adalah semua guru Pendidikan Agama Islam (PAI) di SMA- SMK Negeri Kota Metro dengan jumlah guru sebanyak 30 orang, sehingga penelitian ini termasuk penelitian populasi. Variabel terikat dalam penelitian ini adalah kualitas pengelolaan pembelajaran, sedangkan variabel bebasnya adalah pelatihan dan disiplin mengajar, dengan sifat penelitian adalah kuantitatif

\section{HASIL DAN PEMBAHASAN}

Hasil

Pengaruh pelatihan terhadap kualitas pembelajaran, diperoleh $t_{h i t} \geq t_{d a f \text {, dimana }}$ $t_{\text {hit }}=6,18 \geq t_{\text {daf }}=1,70$ dengan kata lain Ho ditolak, berarti koefisien korelasi persial cukup berarti untuk dijadikan kesimpulan. Artinya ada pengaruh yang kuat antara pelatihan terhadap kualitas pembelajaran. Koefesien korelasi pelatihan adalah $r=0,24$ merupakan suatu korelasi yang cukup dengan koefisien parsial $r 2=0,0576$ sebesar $5,76 \%$. Artinya pengaruh pelatihan terhadap kualitas pembelajaran tergolong cukup, dengan peningkatan sebesar $5,76 \%$ terhadap kualitas pembelajaran guru.

Pengaruh disiplin mengajar terhadap kualitas pembelajaran diperoleh: $t_{\text {hit }} \geq t_{\text {daf, dimana }}$ $t_{\text {hit }}=0,318 \leq 1 t_{\text {daf }}=1,70$ dengan kata lain Ho ditolak, berarti koefisien korelasi persial cukup berarti untuk dijadikan kesimpulan. Artinya ada pengaruh yang kuat antara disiplin mengajar terhadap kualitas pembelajaran. Koefesien korelasi disiplin mengajar adalah $r=0,42$ merupakan suatu korelasi yang cukup dengan koefisien parsial $\mathrm{r} 2=0,1764$ sebesar $17,64 \%$. Artinya pengaruh disiplin mengajar terhadap kualitas pembelajaran tergolong cukup, dengan peningkatan sebesar $17,64 \%$ terhadap kualitas pembelajaran guru. Dengan demikian disiplin mengajar merupakan unsur penting dan cukup dominant dalam mempengaruhi kemampuan guru dalam menciptakan kualitas pembelajaran. 
Pengaruh pelatihan dan disiplin mengajar terhadap kualitas pembelajaran, diperoleh dalam uji keberartian yang telah dilakukan, maka $F_{h i t}=35 \geq F_{d a f}=19,46$. Berarti Ho ditolak, dengan demikain koefesien korelasi multiple berarti untuk dijadikan kesimpulan. Artinya ada pengaruh pelatihan disiplin mengajar terhadap kualitas pembelajaran dengan $R=0,84$ adalah suatu korelasi yang tinggi dengan koefisien persial $\mathrm{R} 2=0,70$ sebesar $70 \%$ terhadap kualitas pembelajaran.

\section{Pembahasan}

Pengaruh Pelatihan (X1) Dan Disiplin Mengajar (X2) terhadap Kualitas Pembelajaran ( Y). Hasil pengujian hipotesis antara pelatihan dan disiplin mengajar terhadap kualitas pembelajaran ditunjukkan dengan korelasi R2 $=0,70$ dengan kontribusi sebesar $70 \%$. Pengujian hipotesis dengan criteria uji $F_{h i t} \geq F_{(1-a)(k, n-k-1)}$ pada taraf signifikansi $a=5 \%$, diperoleh $F_{h i t}=30 \geq F_{\text {daf }}=19,46$ dengan kata lain tolak Ho yang artinya koefesien korelasi multiple cukup berarti untuk dijadikan kesimpulan. Hasil dari perhitungan $t$ dan $r$ dapat diatrikan bahwa ada pengaruh yang berarti antara pelatihan (X1) dan disiplin mengajar (X2) terhadap kualitas pembelajaran (Y). Hasil persamaan regresi antara pelatihan dan disiplin mengajar terhadap kualitas pembelajaran menghasilkan ao $=$ 33,83 , a1 $=0,23$ dan a2 $=0,29$ diperoleh persamaan $Y=33,83+0,32 X 1+0,29 X 2$ dimana $2,43 X 1$ dan $51,3 X 2$ sebagai koefisien arah regresi linier menyatakan perubahan rata- rata variabel $Y$ untuk perubahan variabel $X 2$ untuk perubahan variabel $X 1$ satu- satuan.

Semakin tinggi nilai $\mathrm{X} 1$ dan $\mathrm{X} 2$ maka semakin tinggi nilai $\mathrm{Y}$. pelatihan akan meningkatkan disiplin mengajar, sehingga kualitas pembelajaran meningkat. Keaktifan guru dalam mengikuti pelatihan bertalian erat dengan peningkatan disiplin mengajar. Guru yang aktif dalam mengikuti pelatihan disiplin mengajarnya lebih tinggi dari guru yang kurang aktif dalam mengikuti pelatihan. Menurut Pusat Inovasi Badan Penelitian dan Pengembangan Departemen Pendidikan Nasional, sala satu kategori yang dapat meningkatkan mutu guru dalam pembangunan pendidikan, yaitu sistem pelatihan guru. ( Ondi Saondi dan Aris Suherman,2010:75)

Pada umumnya yang paling banyak dilakukan dalam program pelatihan (inservice training), adalah melalui penataran, yaitu (1) penataran penyegaran, yaitu usaha pengembangan kinerja guru agar sesuai dengan kemajuan ilmu pengetahuan, teknologi dan seni serta menetapkan kinerja guru agar dapat melaksanakan tugas sehari-hari dengan baik. (2) penataran peningkatan kualifikasi, adalah usaha peningkatan kemampuan gurusehinga mereka memperoleh kualifikasi formal tertentu sesuai dengan standar yang ditentukan. (3) penataran penjenjangan, adalah suatu usaha meningkatkan kemampuan guru dalam bidang jenjang struktural sehingga memenuhi persyaratan suatu pangkat atau jabatan tertentu sesuai dengan standar yang ditentukan. (Ondi Saondi dan Aris Suherman,2010:73)

Setiap jenis pekerjaan tidak dapat dipisahkan dari adanya pengetahuan yang relevan, dan pelatihan yang berfungsi memantapkan pengetahuan bidang kerja. Demikian pula halnya dengan bidang kerja/tugas guru. Pelatihan yang diikuti oleh guru memberikan pengaruh terhadap kualitas pembelajaran. Karena dari keaktifan pelaksanaan pelatihan bahkan berdampak pada meningkatnya wawasan guru tentang pentingnya kualitas pembelajaran.

Dalam kegiatan pelatihan terdapat tiga hal penting yang harus diperhatikan, antara lain:

1. Bahwa pelatihan merupakan suatu proses belajar mengajar dengan menggunakan teknik dan metode tertentu.

2. Sebagai suatu proses, maka pelatihan berlangsung relatif lama dan diselenggarakan oleh suatu unit kerja yang melembaga dan kegiatannya diserahkan kepada seseorang atau sekelompok orang yang hendak dialihkan kepada orang lain yang mengikuti program pelatihan.

3. Melalui serangkaian kegiatan, baik yang sifatnya kurikuler maupun ekstra kurikuler yang telah disusun dan dipersiapkan sebelumnya.

Walaupun mungkin terdapat hasil dan dampak pelatihan dibidang lainnya, namun keberhasilan 
suatu pelatihan adalah terjadinya perubahan penampilan yang terukur pada diri peserta atau lulusan program pelatihan. Penampilan tersebut ditandai oleh perubahan, sikap, pengetahuan, ketrampilan dan aspirasi peserta atrau lulusan program pelatihan sebagai sumber daya manusia yang baru dan telah mengalami peningkatan kualitas dirinya.

Untuk mencapai perubahan yang efektif, maka dalam kegiatan pelatihan terdapat langkahlangkah yang harus ditempuh, antara lain seperti dikemukakan Andi Basuki Primabirawa, bahwa:

Untuk mencapai tujuan efektif dalam pelatihan, maka terdapat langkah-langkah antara lain:

1. Identifikasi keadaan yang tidak berubah (status quo) dalam organisasi, dan setelah itu tentukan iklim atau kondisi untuk perubahan.

2. Tetapkan tujuan-tujuan khusus tentang rencana perubahan perilaku yang diusulkan dalam bentuk keluaran (output) sebagai produk, bukan proses atau metode.

3. Susun dan lengkapi metode dan teknik perubahan dengan perangkat (alat bantu) untuk mencairkan perilaku atau kegiatan yang biasa dilakukan saat ini.

4. Kembangkan metode dan teknik untuk belajar tentang perilaku dan prosedur kegiatan baru yang diinginkan.

5. Lengkapi metode dengan alat bantu, yaitu untuk memberi penghargaan terhadap perilaku atau prosedur kegiatan baru.

6. Terapkan metode yang dilengkapi perangkat alat bantu.

7. Laksanakan pelatihan yang telah direncanakan untuk dicapainya perubahan perilaku yang diinginkan.

8. Gunakan metode yang dilengkapi perangkat alat bantu untuk mencapai tujuan.

9. Evaluasi efektifitas perubahan yang telah dilakukan, dan apabila diperlukan buatlah penyesuaian.

Ulangi langkah-langkah di atas sehingga hasil (produk) yang diinginkan tercapai sebagaimana yang direncanakan. ( Andi Basuki Primabirawa,2007:480)

Dalam prakteknya pelatihan sangat berperan dalam meningkatkan kemampuan seseorang dalam meningkatkan efesiensi waktu tenaga dan biaya serta ketrampilan dalam menjalankan pekerjaan. John Kenney dkk mengungkapkan: 'Training helps employees to learn their jobs quickly and effectively. it also helps to minimize the costs incurred by employees while learning their jobs" ( John Kenney dkk.,2007:16)

Pelatihan akan membantu guru mempelajari hakekat dari tugas dan pekerjaan mereka secara cepat dan efektif. Manfaat pelatihan bagi guru, diantaranya : (1) membantu para guru membuat keputusan dengan lebih baik; (2) meningkatkan kemampuan para guru menyelesaikan berbagai masalah yang dihadapinya; (3) terjadinya internalisasi dan operasionalisasi faktor-faktor motivasional; (4) timbulnya dorongan dalam diri guru untuk terus meningkatkan kemampuan kerjanya; (5) peningkatan kemampuan guru untuk mengatasi stress, frustasi dan konflik yang pada gilirannya memperbesar rasa percaya pada diri sendiri; (6) tersedianya informasi tentang berbagai program yang dapat dimanfaatkan oleh para guru dalam rangka pertumbuhan masing-masing secara teknikal dan intelektual; (7) meningkatkan kepuasan kerja; (8) semakin besarnya pengakuan atas kemampuan seseorang; (9) makin besarnya tekad guru untuk lebih mandiri; dan (10) mengurangi ketakutan menghadapi tugas-tugas baru di masa depan. ( Sondang P. Siagian,1991)

Dalam sistem pelatihan, langkah-langkah yang dapat diambil adalah sebagai berikut:

1. Perlunya revitalisasi pelatihan guru yang secara khusus dititikberatkan untuk memperbaiki kinerja guru dalam meningkatkan mutu pendidikan dan bukan untuk meningkatkan sertifikasi mengajar semata-mata.

2. Perlunya mekanisme control penyelenggaraan pelatihan guru untuk memaksimalkan pelaksanaannya.

3. Perlunya sistem penilaian yang sistem penilaian yang sistemik dan periodic untuk mengetahui efektivitas dan dampak pelatihan guru terhadap mutu pendidikan.

4. Perlunya desentralisasi pelatihan guru pada tingkat kabupaten/ kota sesuai dengan perubahan 
mekanisme kelembagaan otonomi daerah yang dituntut dalam UU No.22/1999.

Berdasarkan pada uraian di atas, maka dapat diketahui bahwa pelatihan berpengaruh terhadap terbentuknya kesadaran dan sikap guru dalam menghadapi tugas mengajar. Karena dari pelatihan yang diperoleh, maka guru semakin bertambah wawasan, pengetahuan dan pengalamannya dalam hal mengajar dan akan memudahkan guru dalam mewujudkan pembelajaran yang berkualitas.

Selain pelatihan, aktivitas yang maksimal disiplin guru sangat mendukung terhadap usaha mewujudkan pembelajaran yang berkualitas. Disiplin merupakan sikap taat atau tunduk pada diri seseorang atau sekelompok orang terhadap tata aturan yang berlaku pada suatu lingkungan tertentu. Sikap disiplin ada yang positif dan ada yang negatif, karena itu disiplin sebagai ciri atau suatu sikap juga merupakan karakter yang perlu dimiliki oleh setiap individu termasuk guru. Kedisiplinan juga merupakan karakter suatu organisasi, lembaga atau instansi tertentu, di mana di dalamnya terdapat sejumlah orang yang saling bekerjasama dengan penuh tanggung jawab, tunduk kepada peraturan yang berlaku dan memegang teguh prinsip, norma kerja, dan etika kerja.

Adapun beberapa faktor yang dapat mempengaruhi disiplin seseorang, diantaranya adalah seperti yang dikemukakan oleh Ameruddin Syarief sebagai berikut: "Faktor-faktor yang dapat mempengaruhi disiplin seseorang antara lain adalah: Motivasi, pendidikan dan latihan, kepemimpinan, kesejahteraan, dan penegakan disiplin". ( Amerudin Syarif:21)

Kemudian dikatakan cukup atau sedang, jika sebagian besar indikator tersebut dipatuhi/dijalankan oleh guru. Selanjutnya jika guru hanya melaksanakan sebagian kecil saja bahkan sering melanggar tata aturan tersebut, maka dapat dikatakan bahwa disiplin guru tersebut rendah.

Kemudian menurut Ameruddin Syarief bahwa sebenarnya tidak sulit mengkriteriakan disiplin seseorang, baik dalam bekerja, atau dalam menjalankan tugas lainnya. Misalnya dalam bekerja, dapat dilihat dari segi sikap, cara bekerja, cara mematuhi peraturan sekolah, dan indikator sikap lainnya. ( Amerudin Syarif:27)

Berbagai macam bentuk pelatihan yang diikuti oleh guru dan sikap disiplin akan membantu meningkatkan sebuah bentuk pelayanan yang maksimal yang dilakukan oleh guru terhadap siswanya dalam pelaksanaan proses pembelajaran.

Berdasarkan uraian di atas dapat disimpulkan bahwa berdasalkan hasil penelitian, kegiatan pelatihan dan sikap disiplin guru memberikan sumbangan/ sangat berpengaruh terhadap kualitas pengelolaan pembelajaran seorang guru. Dalam melaksanakan pembelajaran guru harus berusaha untuk memperoleh pelatihan yang diperlukan sehingga mampu meningkatkan disiplin mengajarnya dan pada akhirnya mampu mewujudkan pengelolaan pembelajaran yang berkualitas.

\section{PENUTUP}

Secara umum ada pengaruh yang signifikan antara pelatihan dan disiplin mengajar terhadap kualitas pengelolaan pembelajaran guru PAI SMA-SMK di kota Metro. Implikasi dari temuan penelitian ini adalah bahwa Kegiatan pelatihan penting bagi setiap guru, karena melalui pelatihan, guru dihadapkan langsung kepada contoh-contoh peristiwa yang nyata dalam pembelajaran, sehingga guru akan mampu secara baik dalam pembuatan perangkat pembelajaran, penyediaan sumber bahan, pemilihan dan penerapan metode mengajar, pemilihan media dan sumber, dan aspek-aspek lainnya. Banyak sedikitnya guru mengikuti pelatihan ini akan membedakan tingkat pengalaman yang ada pada guru dan sekaligus sebagai bekal dalam menjalankan kegiatan pembelajaran.

Selain itu implikasi dari sistem pelatihan guru dapat berupa (1) adanya sistem pelatihan guru yang didahului dengan need assessment sesuai kondisi daerah masing-masing, (2) adanya sistem monitoring penyelengaraan pelatihan guru yang dikoordinasikan dengan lembaga-lembaga pengelola pendidikan, (3) adanya lembaga swasta yang independen yang bertugas melakukan penilaian-penilaian proses (Formative evaluation), dan dampak pelatihan guru untuk menemukan model-model pelatihan guru yang efektif dan efisien dalam meningkatkan mutu pendidikan, (4) pembentukan dan 
pemberdayaan sentra-sentra pelatihan guru di kabupaten/kota yang juga bertugas untuk mengembangkan konten dan strategi mengajar tepat guna yang mampu meningkatkan kinerja guru dalam mengelola proses pembelajaran.

Demikian pula dengan sikap kedisiplinan seorang guru, Disiplin merupakan unsur penting dalam berbagai bidang kehidupan, termasuk dalam hal kinerja guru. Karena dalam menjalankan suatu pekerjaan, seseorang ingin mencapai tujuan dan melalui sikap disiplin, maka tujuan akan tercapai. Guru sebagai pendidik harus mau mengembangkan dirinya dengan mengikuti berbagai kegiatan pelatihan dan meningkatkan sikap disiplin guna meningkatkan kualias pengelolaan pembelajaran.

\section{UCAPAN TERIMAKASIH}

Ucapan terimakasih ditujukan kepada SMK Negeri 3 Metro dan SMA/SMK Negeri Se-kota Metro yang telah memberikan kontribusi dalam penelitian. Terimakasih juga kepada Pengelola Jurnal Al l'tibar atas terpublikasinya hasil penelitian ini.

\section{DAFTAR PUSTAKA}

Abdul Azis Wahab, (2007). Pendidikan Lintas Bidang, FIP-UP, Jakarta.

Andrew E. Sikula,(2007). Training and Development Hanbook, a Guide to Human Recource Development, Mc Graw Hill Book Company, New York.

Andi Basuki Primabirawa,(2007). IImu dan Aplikasi Pendidikan, Imtima, Jakarta.

Anonim,(2000). Kamus Bahasa Indonesia, Balai Pustaka, Jakarta.

AF. Tangyong, (1994). Pendidikan Keterampilan Proses dalam Pembelajaran, Rajawali, Jakarta.

Arief Sadiman, (2000). Teknik Dan Analisis Penelitian, Erlangga, Jakarta.

Achmad Hinduan,(2007). Pelatihan Untuk Perubahan, Imtima, Jakarta.

Amerudin Syarif, (2002). Pembinaan Pegawai Negeri Sipil, Depdiknas, Jakarta.

Daeng Sudirwo,(2002). Kurikulum Pembelajaran Dalam Rangka Otonomi Daerah, Andira, Bandung.

Departemen Agama RI, AlQur'an dan terjemahan

Depdikbud RI, (1984). Proses Belajar Mengajar, Akta Mengajar IV, Jakrta.

Depdiknas,(2005). UU Sidiknas, Depdiknas, Jakarta.

, (2007). Pengembangan IImu Pendidikan, Jakarta.

Friedman dan Yarbrough, (1985). Approaches to Training and Development, Addison Wesley Publising Company, New York.

Filipo, Moekijat,(2002). Dasar-Dasar Kepemimpinan, LP3ES, Jakarta.

Hamzah B. Uno, (1998). Teori Belajar dan Pembelajaran (Suatu Pengantar), STKIP Gorontalo, Nurul Jannah.

Hamzah B. Uno, (2009). Perencanaan Pembelajaran, Bumi Aksara, Jakarta.

Hanafiah dan Cucu Suhana, (2010). Konsep Strategi pembelajaran, Refika Aditama, Bandung.

Indriyo Gito Sudarmo dan Agus Mulyono.(1990). Prinsip Dasar Manajemen (edisi 3). BPFE, Yogyakarta.

I.L. Pasaribu, (2000). Administrasi Pendidikan, Rajawali, Jakarta.

I Nyoman Sudana Degeng, (1993). Buku Pegangan Teknologi Pendidikan, Pusat antar Universitas untuk Peningkatan dan Pengembangan Aktivitas Instruksional Universitas Terbuka, DepDikbud RI, Dirjen Dikti, Jakarta.

Jakub Hidayat, (1999). Psikologi Pendidikan, UT, Jakarta.

John Kenney, (2007). Eugene Donnelly, Margaret Reid, Manpower Training and Development.

Koesjono, (1998). Hakekat Manusia Bekerja, UT, Jakarta.

---------, (2000). Ketenagakerjaan, UT, Jakarta.

K. Sukarji, (2000). Ilmu Pendidikan dan Pengajaran Agama, Indra Jaya, Jakarta.

Marlina, M. (2019). Studi Korelasi Disiplin Dalam Pembelajaran Dengan Kinerja Guru Di SMAN SeKecamatan Bumi Agung Kabupaten Way Kanan. Al-l'tibar : Jurnal Pendidikan Islam, 6(1), 4549. https://doi.org/10.30599/jpia.v6i1.566

Moekijat, (2001). Manajemen Dasar dan Kepemimpinan, Ghalia Indonesia, Jakarta.

Mudhoffir, (1991). Pengembangan Pembelajaran, Tarsito, Bandung.

Muhammad Ali, (2004). Kamus Bahasalndonesia, Rajawali, Jakarta.

Munandir, (1992). Rancangan Sistem Pengajaran, Direktorat Jenderal Perguruan Tinggi, P2LPTK, Jakarta.

Nana Syaodih Sukmadinata, (2007). IImu dan Aplikasi Pendidikan, FIP UPI, Jakarta. 
Oemar Hamalik, (2004). Pendidikan Guru Berdasarkan Pendekatan Kompetensi, Bumi Aksara, Jakarta.

Ondi Saondi dan Aris Suherman, (2010). Etika Profesi Keguruan, Refika Aditama, Bandung.

Oteng Sutisna, (1997). Melatih Sikap Disiplin, Grafika, Bandung.

Pupuh Fathurrohman, M. Sobri Sutikno, (2007). Strategi Belajar Mengajar Melalui penanaman Konsep Umum dan Konsep Islami, RefikaAditama, Bandung.

Sastrodiningrat, (2003). Perilau Administrasi, UT, Jakarta.

Sri Soekami RB, (2001). Ketenagakerjaan UT, Jakarta.

Sugiyono, (2003). Metode Penelitian, Erlangga, Jakarta.

, (2010). Metodologi Penelitian Kuantitatif Kualitatif dan R \& D, Alfabeta, Bandung.

Suharsimi Arikunto, (2008). Prosedur Penelitian, Rineka Cipta, Jakarta.

Sukardi, (2007). Metodologi Penelitian Pendidikan (Kompetensi dan Praktiknya), Bumi Aksara, Jakarta.

Sutrisno Hadi,(2001). Metodologi Research Jilid II, UGM, Jogjakarta.

Soekardi, (2007). Evaluasi Pendidikan, Usaha Nasional Surabaya.

Sondang P. Siagian .1991. Manajemen Sumber Daya Manusia. Jakarta: Bumi Aksara

Syaiful Sagala, (2006). Manajemen Berbasis Sekolah dan Masyarakat (Strategi memenangkan persaingan mutu), PT Nimas Multima, Jakarta.

Tim Pustaka Phoenix,(2009). Kamus Besar Bahasa Indonesia, Media Pustaka Phoenix, Jakarta.

Undang-undang Sistem Pendidikan Nasional No.2/ th 1989

Undang-undang Sistem Pendidikan Nasional No. 20/ th 2003

Uzer Usman,(2002). Menjadi Guru Profesional, Rosdakarya, Bandung.

Winardi, (2001) . Motivasi \& Pemotivasian dalam Manajemen. PT Radja Grafindo Pers, Jakarta.

WJS Purwdarminta, (2002). Kamus Umum Bahasa Indonesia, Balai Putaka Jakarta. 